\title{
Evaluation of Physico-Mechanical-Combustion Characteristics of Fuel Briquettes Made from Blends of Areca Nut Husk, Simarouba Seed Shell and Black Liquor
}

\author{
Santhosh Ujjinappa $\mathrm{a}^{\mathrm{a}^{*}}$ and Lingadhalli Krishnamurthy Sreepathi ${ }^{\mathrm{b}}$ \\ ${ }^{a}$ Department of Mechanical Engineering, AMC Engineering college, Bangalore, Karnataka, India \\ ${ }^{b}$ Department of Mechanical Engineering, Jawaharlal Nehru National College of Engineering, Shivamogga, Karnataka, India
}

\begin{abstract}
In order to utilize the agro residues and non-edible oil seed shells for the energy purpose, Areca Nut Husk (ANH) and Simarouba Seed Shell (SSS) are considered as raw materials and pulp production industry byproduct Black liquor (BL) as a binder for the production of fuel briquettes. The cylindrical briquettes were produced in four different blending proportions at 3 different pressures between $60 \mathrm{MPa}$ to $80 \mathrm{MPa}$ and various briquette properties were evaluated. The mathematical regression equations between the independent variables (blending proportion and compacting pressure) and briquette properties were developed. The $R^{2}$ values for the regression equation between independent variables and (Briquette properties) compressed density, relaxed density, relaxation ratio, shattering index and compressive strength were $0.945,0.743,0.646,0.862$ and 0.839 respectively. The results confirmed that briquette produced with a blending proportion of $\mathrm{ANH}: \mathrm{SSS}: \mathrm{BL}=60: 40: 00$ at $80 \mathrm{MPa}$ have better properties. Thus, combustion characteristics such as proximate analysis, ultimate analysis, calorific value were estimated for a briquette produced with a blending proportion of ANH:SSS:BL=60:40:00 at $80 \mathrm{MPa}$; and compared with Barley and Sawdust charcoal briquettes. The overall results conclude that better quality briquettes can be produced from the blends of ANH and SSS and can be used for several heating applications.
\end{abstract}

Keywords: fuel; biomass; briquette; agro residue; non-edible oil seed shell

Article History: Received Dec 15th 2017; Received in revised form May 16 ${ }^{\text {th }}$ 2018; Accepted June 3rd 2018; Available online

How to Cite This Article: Ujjinappa, S. and Sreepathi, L.K. (2018) Evaluation of Physico-Mechanical-Combustion Characteristics of Fuel Briquettes Made From Blends of Areca Nut Husk, Simarouba Seed Shell and Black Liquor. Int. Journal of Renewable Energy Development, 7(2), $131-137$.

https://doi.org/10.14710/ijred.7.2.131-137

\section{Introduction}

Economy of many developing countries is majorly affected by importing fossil fuels and hence, biomass plays a key role to produce quality sustainable renewable energy fuel to replace fossil fuel (Karin \& Rodrigo 2012). The scope of biomass crop is very high for energy production, which is producing about 8 times the world energy consumption per year, but effective utilization is very less. The biomass is carbon neutral and produces very less $\mathrm{NO}_{\mathrm{x}}$, $\mathrm{SO}_{\mathrm{x}}$ emissions compared to fossil fuels (Yufu et al. 2011). Biomass raw materials have received more attention due to their tremendous diversity, which contain agricultural residues, food waste, paper, green waste, municipal solid waste, cardboard and other waste (Demirbas 2009). But direct combustion of biomass is inefficient because it produces lot of fly ash which leads to the release of unburnt carbon into the atmosphere, this difficulty can be overcome by briquetting (Paul, Rajan \& Dasappa 2014). Antwi \& Acheampong (2016) defined that briquetting is a process of compressing low density biomass residues to produce high density solid block, which can be used as a substitute for coal in boilers, furnaces and as a heat source for domestic cooking. Kalyani et al. (2016) concluded that biomass briquetting shows potential toward cleaner energy application and can emerge as a beneficial alternative for rural people and other uses.

Rajaseenivasan et al. (2016) discussed the performance of the various blends of neem powder and sawdust briquette, results indicate that strength of the briquette increased with the increase of neem powder but a small decrease in burning rate. Antwi \& Acheampong (2016) used assorted sawdust and logging residues to produce better quality briquettes which helps to meet the current power requirement and reduces emissions as compare to fossil fuel.

Shiv et al. (2013) concluded that India has good tropical condition to grow non-edible seed-bearing trees. Biodiesel from non-edible seed is a possible substitute to reduce the usage of petroleum based diesel fuel and deaccelerate the $\mathrm{CO}_{2}$ emissions. Mishra et al. (2012) stated that at present biodiesel is one of the most important fuel to replace petroleum diesel. Simarouba glauca seed is one of the

\footnotetext{
* Corresponding author: santhoshujjinappa1986@gmail.com
} 
potential non-edible resource available in India to produce biodiesel and it could help to increase the income of poor people. India produces approximately 7,700 tons of simarouba glauca seeds per year and residue production ratio is 1.45 which was calculated in the present study, generates 11,200 tons of seed shell per year (shiv et al. 2013; Syamasundar \& Shantha 2008).

Soumya, Vaibhav \& Kaustubha (2012) suggested that areca nut husk can be used as a source of lignocellulosic biomass for biofuel production and physicochemical characterization of these biomasses surely opens opportunity of selecting future biofuel in north-east region of India. In India and other developing countries many villages have no electricity connection for example Sandeep (2017) stated that as many as 32 villages and 16.88 lakh households in Karnataka are still living without electricity. India is the number one producer of areca nut in the world and according to agricultural statistics, India had produced 7.32 lakh tons of areca nut during 2014-15 (Sangeeta 2015). Residue production ratio of areca nut is 0.8 (Moonmoon, Dhiman \& Baruah 2014) which generates 5.856 lakh tons of areca nut husk. Disposal of areca nut husk is a problem for farmers in areca nut growing villages and it can be considered as a potential biomass resource to produce heat.

In the above context, the aim of the study was to utilize the Simarouba Seed Shell (SSS) and Areca Nut Hush (ANH) with Black Liquor (BL) as an additive for the production of fuel briquettes and examine the mixing proportions on the properties of the briquettes.

\section{Materials and Methods}

\subsection{Materials}

The raw materials areca nut husk was collected from the local village near Chikmangalur, Karnataka, India; simarouba seed shell was collected from district bioenergy information and demonstration centre, Shimoga, Karnataka, India; and black liquor was collected form Harihar polyfibers and grasilene division, Harihar, Karnataka, India. The raw materials were sundried for seven days to remove the moisture content and grinded using a hammer mill. The raw material particle sizes of areca nut husk and simarouba seed shell used in this study were $1 \mathrm{~mm}$ or less.

Table 1.

Combustion characteristics of Areca Nut Husk (ANH) and Simarouba Seed shell (SSS)

\begin{tabular}{lcc}
\multirow{2}{*}{ Property } & \multicolumn{2}{c}{ Raw Material } \\
\cline { 2 - 3 } & $\mathrm{SSS}^{\mathrm{a}}$ & $\mathrm{ANH}^{\mathrm{b}}$ \\
\hline Proximate analysis (on as received basis, wt. \%) & \\
Moisture & 6.17 & 12.50 \\
Volatile matter & 77.50 & 62.97 \\
Fixed carbon & 13.36 & 18.93 \\
Ash & 2.97 & 5.6 \\
Ultimate analysis (on dry and ash-free basis, wt. \%) \\
C & 63.68 & 47.89 \\
$\mathrm{H}$ & 7.00 & 5.93 \\
$\mathrm{~N}$ & 0.55 & 3.08 \\
O & 19.47 & 43.10 \\
Calorific value $(\mathrm{MJ} / \mathrm{kg})$ & 16.79 & 17.90 \\
\hline
\end{tabular}

a Present study

b Mythili et al. 2013
The blending proportions of ANH to SSS to BL are 60:40:00(S1), 60:35:05(S2), 60:30:10(S3), 60:25:15(S4) by mass. The proximate analysis, ultimate analysis and calorific value of ANH and SSS are shown in Table 1.

\subsection{Production of briquettes}

Briquettes were produced using a multi briquetting die with a capacity of four briquettes was fabricated in S. R. Industries, Peenya II Stage, Bangalore. The components of the briquetting die are a solid circular block consisting of 4 cylindrical holes, pistons, horizontal metal plates and a hollow circular block. Place the briquetting die in the Universal Testing Machine (Fig. 1) and the force generated by the UTM drive the pistons through the holes and compress the raw material in the holes. The ground raw material to be briquetted is put into the holes, the upward moving of circular block compresses the raw material at a pressure of $60 \mathrm{MPa}, 70 \mathrm{MPa}$ and $80 \mathrm{MPa}$ against the top horizontal plate with a dwell time of $60 \mathrm{~s}$. Once the raw material is compressed in briquetting die, release the pressure and replace the bottom horizontal plate by hollow circular block. Again, apply force which drives the piston through the holes and remove the briquettes from the briquetting die. Fig. 2 shows some of the briquettes produced at different pressure.

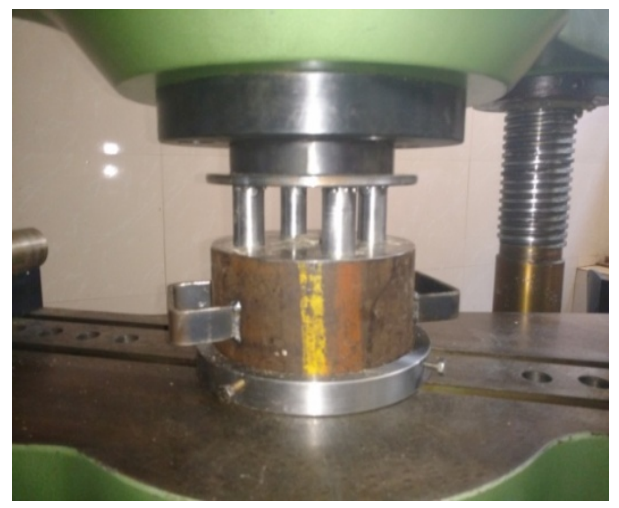

Fig. 1 Multi briquetting die loaded in UTM

\subsection{Properties of briquettes}

The compressed density of the briquettes was determined immediately after ejection from the die as a ratio of measured mass over calculated volume (Obi, Akubuo \& Okonkwo 2013). Relaxed density (RD) of the briquettes was determined 30 days after removal from the press in accordance to ISO 3131 (1975). Relaxation ratio is the ratio of compressed density to relaxed density of briquettes.

Shattering index of briquettes was measured according to ASTM D440-86 (1998) of drop shatter developed for coal. The test was conducted after two weeks of briquettes samples formation. Compressive strength of briquettes was determined in accordance to ASTM D216685 (2008) using an instron universal strength testing machine with a load cell capacity of $500 \mathrm{~kg}$ and a crosshead speed was $0.305 \mathrm{~mm} / \mathrm{min}$. All the briquetting properties were evaluated for three times and values represent averages of the results obtained from three independent experiments. The mathematical regression 
equations for briquetting properties were developed using IBM-SPSS statistics software.

\subsection{Combustion characteristics of briquettes}

Combustion characteristics such as the proximate analysis were estimated according to IS:1350, Part-I (1984), the ultimate analysis were estimated according to Indian Standard (Determination of Sulphur, IS:1350,
Part-III,1969; Determination of Carbon and Hydrogen, IS:1350, Part-IV/Sec1,1974; Determination of Nitrogen, IS:1350, Part-IV/Sec 2,1975) and the calorific value was estimated according to IS:1350, Part-II (1970) which identifies the quality of fuel.

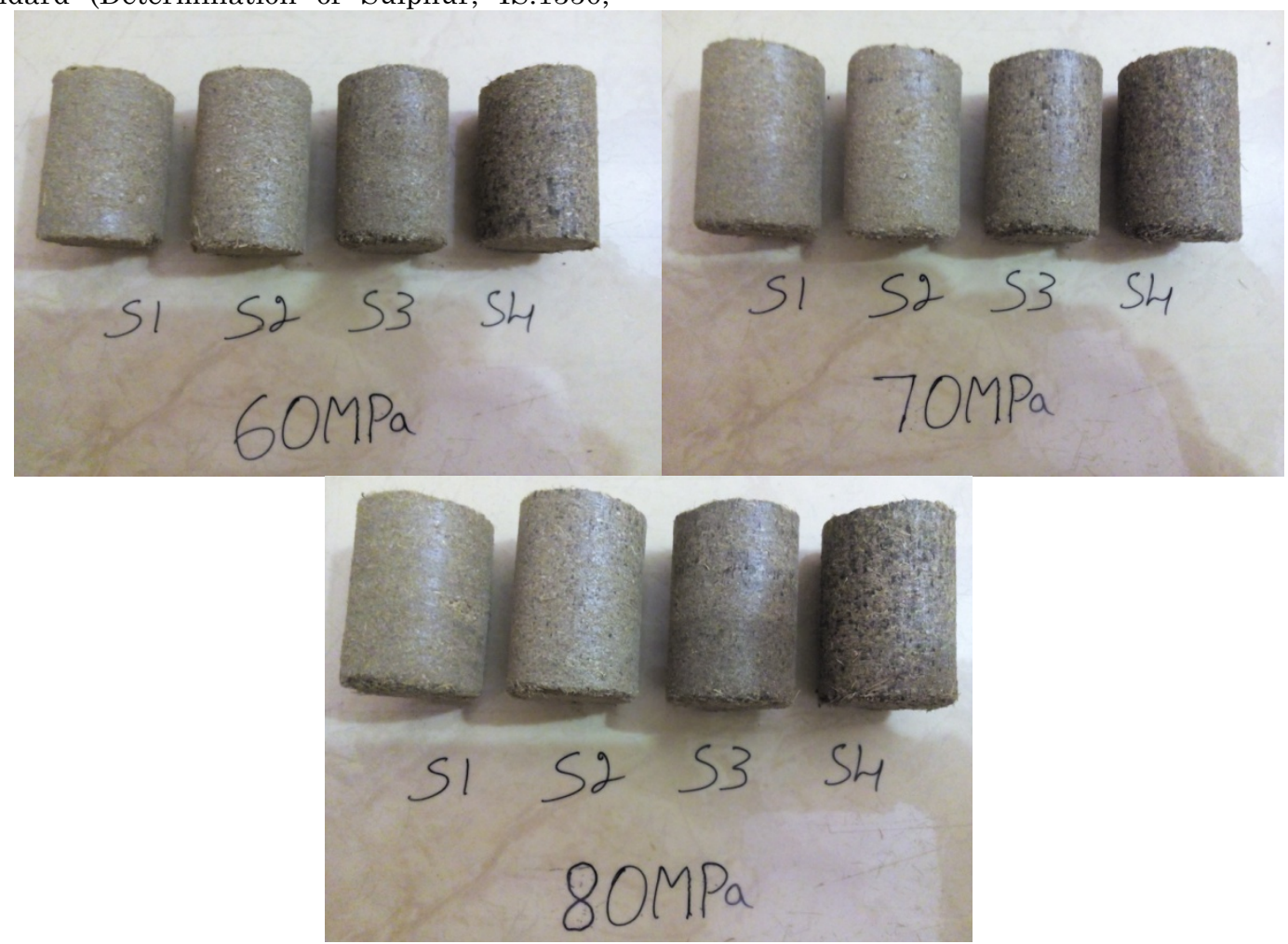

Fig. 2 Briquettes produced at different pressures.

\section{Results and discussions}

\subsection{Effect of pressure and binder level on the properties of briquettes}

Fig. 3 describes the compressed density of briquettes produced in different blending proportions and at different compacting pressures with linear equations. The compressed density of the briquette increases as the binder level increases at all pressures with increased compressive density, 1001 to $1040 \mathrm{~kg} / \mathrm{m}^{3}$ for $\mathrm{S} 1,1012$ to $1066 \mathrm{~kg} / \mathrm{m}^{3}$ for $\mathrm{S} 2,1022$ to $1088 \mathrm{~kg} / \mathrm{m}^{3}$ for $\mathrm{S} 3$, while 1035 to $1113 \mathrm{~kg} / \mathrm{m}^{3}$ for $\mathrm{S} 4$. The lowest compressed density 1001 $\mathrm{kg} / \mathrm{m}^{3}$ was obtained for $\mathrm{S} 1$ at $60 \mathrm{MPa}$ and the highest 1113 $\mathrm{kg} / \mathrm{m}^{3}$ was obtained for $\mathrm{S} 4$ at $80 \mathrm{MPa}$. Similar results were obtained for briquettes produced using blends of sawdust and palm kernel shell (Okey 2015), rice husk and palm oil mill sludge (Okey \& Kingsley 2016). The mathematical regression equation for compressed density (CD) depends on blending proportion (BP) and compacting pressure (CP) with the $R^{2}$ and probability values of 0.945 and 0.000 respectively, is represented in Eq. (1).

Compressed density $\left(\mathrm{kg} / \mathrm{m}^{3}\right)=795.458+16.6 \mathrm{BP}+$ $2.963 \mathrm{CP}$

The theoretical and experimental values of compressed densities are shown in the Table 2.

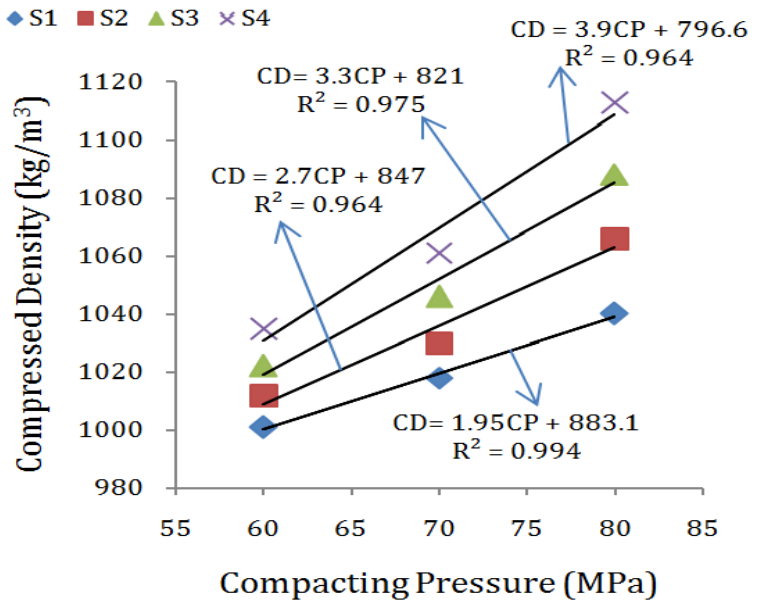

Fig. 3 Briquette compressed density as a function of compacting pressure and binder level.

Fig. 4 describes the relaxed density of briquettes produced in different blending proportions and at different compacting pressures with linear equations. Due to dilation the relaxed density of briquettes are lower than the compressed density of same briquettes at all pressures and all binder levels. The relaxed density varies from 890 
Citation: Ujjinappa, S and Sreepathi, L.K. (2018) Evaluation of Physico-Mechanical-Combustion Characteristics of Fuel Briquettes Made From Blends of Areca Nut Husk, Simarouba Seed Shell and Black Liquor. Int. Journal of Renewable Energy Development, 7(2), 131-137, doi.org/10.14710/ijred.7.2.131-137.

P a g e | 134

to $962 \mathrm{~kg} / \mathrm{m}^{3}$ for $\mathrm{S} 1,884$ to $920 \mathrm{~kg} / \mathrm{m}^{3}$ for $\mathrm{S} 2,895$ to 930 $\mathrm{kg} / \mathrm{m}^{3}$ for $\mathrm{S} 3$, while 898 to $938 \mathrm{~kg} / \mathrm{m}^{3}$ for $\mathrm{S} 4$. The lowest relaxed density $884 \mathrm{~kg} / \mathrm{m}^{3}$ was obtained at $\mathrm{S} 2$ at $60 \mathrm{MPa}$ and highest $962 \mathrm{~kg} / \mathrm{m}^{3}$ was obtained for $\mathrm{S} 1$ at $80 \mathrm{MPa}$. The results obtained in this study is consistent with the research findings by (Okey 2015; Okey \& Kingsley 2016; Davies \& Davies 2014). The mathematical regression equation for relaxed density (RD) depends on blending proportion $(\mathrm{BP})$ and compacting pressure $(\mathrm{CP})$ with the $\mathrm{R}^{2}$ and probability values of 0.743 and 0.000 respectively, is represented in Eq. (2).

Relaxed density $\left(\mathrm{kg} / \mathrm{m}^{3}\right)=752.542-0.762 \mathrm{BP}+2.288 \mathrm{CP}$

The theoretical and experimental values of relaxed densities are shown in the Table 2

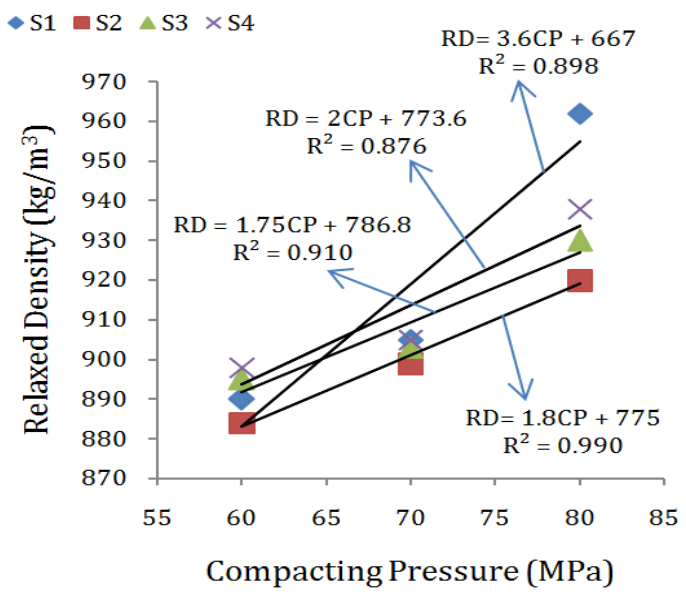

Fig. 4 Briquette relaxed density as a function of compacting pressure and binder level.

The stability of briquettes with respect to density can be identified by the relaxation ratio and stability of briquettes varies inversely proportional to the relaxation ratio (Okey \& Kingsley 2016). Fig. 5 describes the relaxation ratio of briquettes produced in different blending proportions and at different compacting pressures with linear equations. The relaxation ratio of briquettes decreases as the pressure increases at $0 \%$ binder level (S1) and for other samples (S2, S3 and $\mathrm{S} 4$ ) increases as the pressure increases.

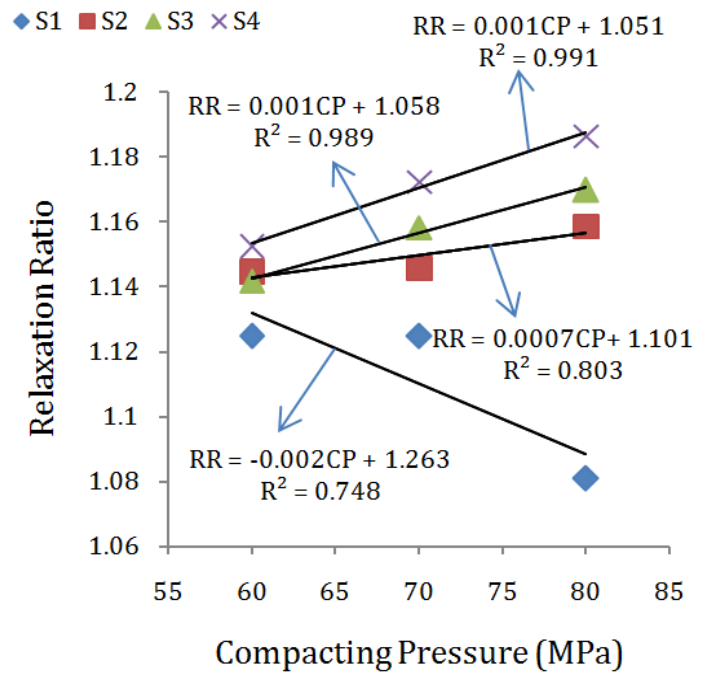

Fig. 5 Briquette relaxation ratio as a function of compacting pressure and binder level.

The highest relaxation ratio 1.1865 was obtained for $\mathrm{S} 4$ at $80 \mathrm{MPa}$ and lowest 1.0810 was obtained for $\mathrm{S} 1$ at $80 \mathrm{MPa}$. As the stability of briquettes varies inversely proportional the briquettes produced with $0 \%$ binder level at $80 \mathrm{MPa}$ has better quality as compared to all briquettes produced at other binder levels and pressures. The results obtained in this study are consistent with the research findings by (Okey 2015; Okey \& Kingsley 2016; Davies \& Davies 2014). The mathematical regression equation for relaxation ratio (RR) depends on blending proportion (BP) and compacting pressure $(\mathrm{CP})$ with the $\mathrm{R}^{2}$ and probability values of 0.646 and 0.000 respectively, is represented in Eq. (3).

Relaxed ratio $=1.072+0.019 \mathrm{BP}+0.000403 \mathrm{CP}$

The theoretical and experimental values of relaxed densities are shown in the Table 2.

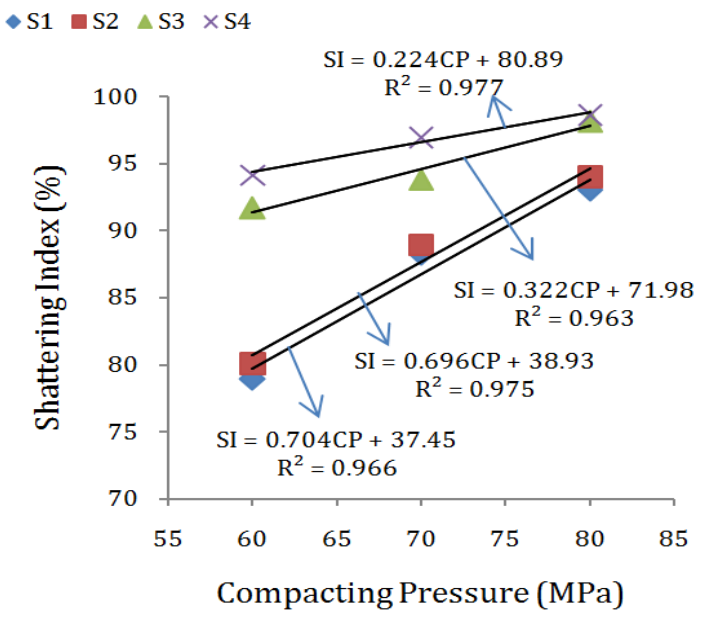

Fig. 6 Briquette shattering index as a function of compacting pressure and binder level. 
Table 2.

Comparison of theoretical and experimental values of properties of briquettes.

\begin{tabular}{|c|c|c|c|c|c|c|c|c|c|c|c|}
\hline \multirow{2}{*}{$\begin{array}{c}\text { Raw material } \\
\text { blending } \\
\text { proportion } \\
\text { (AH:SSS:NL) }\end{array}$} & \multirow{2}{*}{ 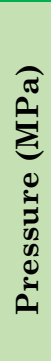 } & \multicolumn{2}{|c|}{$\begin{array}{c}\text { Compressed } \\
\text { Density } \\
\left(\mathrm{kg} / \mathrm{m}^{3}\right)\end{array}$} & \multicolumn{2}{|c|}{$\begin{array}{l}\text { Relaxed } \\
\text { density } \\
\left(\mathbf{k g} / \mathrm{m}^{3}\right)\end{array}$} & \multicolumn{2}{|c|}{ Relaxation ratio } & \multicolumn{2}{|c|}{$\begin{array}{l}\text { Shattering } \\
\text { Index }(\%)\end{array}$} & \multicolumn{2}{|c|}{$\begin{array}{l}\text { Comressive } \\
\text { strength } \\
(\mathrm{N} / \mathrm{mm})\end{array}$} \\
\hline & & 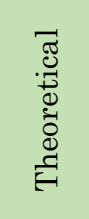 & 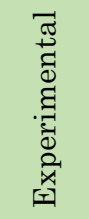 & 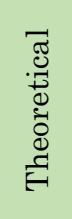 & 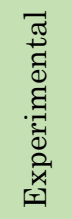 & 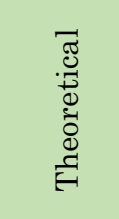 & 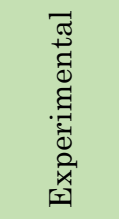 & 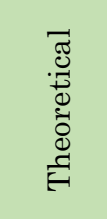 & 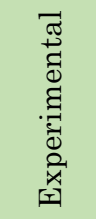 & 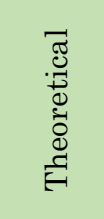 & 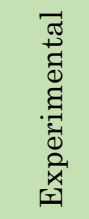 \\
\hline \multirow{3}{*}{$\begin{array}{c}\text { S1 } \\
(60: 40: 00)\end{array}$} & 60 & 990 & 1001 & 889 & 890 & 1.1151 & 1.1247 & 81.06 & 78.93 & 20.09 & 18.98 \\
\hline & 70 & 1019 & 1018 & 912 & 905 & 1.1192 & 1.1248 & 85.93 & 88.25 & 23.59 & 25.14 \\
\hline & 80 & 1049 & 1040 & 935 & 962 & 1.1232 & 1.0810 & 90.80 & 93.01 & 27.09 & 29.15 \\
\hline \multirow{3}{*}{$\begin{array}{c}\mathrm{S} 2 \\
(60: 35: 05)\end{array}$} & 60 & 1006 & 1012 & 888 & 884 & 1.1341 & 1.1447 & 84.71 & 80.09 & 19.33 & 19.12 \\
\hline & 70 & 1036 & 1030 & 911 & 899 & 1.1382 & 1.1457 & 89.58 & 88.97 & 22.83 & 20.25 \\
\hline & 80 & 1066 & 1066 & 934 & 920 & 1.1422 & 1.1586 & 94.45 & 94.02 & 26.33 & 25.55 \\
\hline \multirow{3}{*}{$\begin{array}{c}\text { S3 } \\
(60: 30: 10)\end{array}$} & 60 & 1023 & 1022 & 887 & 895 & 1.1531 & 1.1418 & 88.36 & 91.70 & 18.56 & 19.47 \\
\hline & 70 & 1053 & 1046 & 910 & 903 & 1.1572 & 1.1583 & 93.23 & 93.84 & 22.06 & 20.93 \\
\hline & 80 & 1082 & 1088 & 933 & 930 & 1.1612 & 1.1698 & 98.10 & 98.15 & 25.56 & 25.21 \\
\hline \multirow{3}{*}{$\begin{array}{c}\mathrm{S} 4 \\
(60: 25: 15)\end{array}$} & 60 & 1040 & 1035 & 887 & 898 & 1.1721 & 1.1525 & 92.01 & 94.17 & 17.80 & 20.41 \\
\hline & 70 & 1069 & 1061 & 909 & 905 & 1.1762 & 1.1723 & 96.88 & 97.00 & 21.30 & 20.81 \\
\hline & 80 & 1098 & 1113 & 933 & 938 & 1.1802 & 1.1865 & 101.7 & 98.66 & 24.80 & 25.11 \\
\hline
\end{tabular}

The resistance to become few finer particles of briquettes during storing and transportation can be identified by shattering index. Fig. 6 describes the shattering index of briquettes produced in different blending proportions and at different compacting pressures with linear equations. The shattering index of briquettes increases as the binder level increases at all pressures. The lowest shattering index $78.93 \%$ was obtained for $\mathrm{S} 1$ at $60 \mathrm{MPa}$ and highest shattering index $98.66 \%$ was obtained for S4 at $80 \mathrm{MPa}$. According to Antwi \& Acheampong (2016), if the briquette shattering index reaches a value higher than $90 \%$ is acceptable and will be having stability during manipulation. The shattering index of briquette samples $\mathrm{S} 1$ and $\mathrm{S} 2$ produced at $60 \mathrm{MPa}$ and $70 \mathrm{MPa}$ are less than $90 \%$ and all other samples at all pressures are more than $90 \%$. The shattering index is a function of applied pressure, binder level, raw material particle size and ash content. Higher the applied pressure, higher the binder level enhances the shattering index; and lower the raw material particle size, lower the ash content also enhances the shattering index of briquettes. The results obtained in this study are consistent with the research findings by (Okey 2015; Okey \& Kingsley 2016; Davies \& Davies 2014). The mathematical regression equation for shattering index (SI) depends on blending proportion (BP) and compacting pressure $(\mathrm{CP})$ with the $\mathrm{R}^{2}$ and probability values are 0.862 and 0.000 respectively, is represented in Eq. (4).

Shattering index $(\%)=48.19+3.651 \mathrm{BP}+0.487 \mathrm{CP}$

The theoretical and experimental values of shattering index are shown in the Table 2. $\bullet \mathrm{S} 1 \square \mathrm{S} 2 \triangle \mathrm{S} 3 \times \mathrm{S} 4$

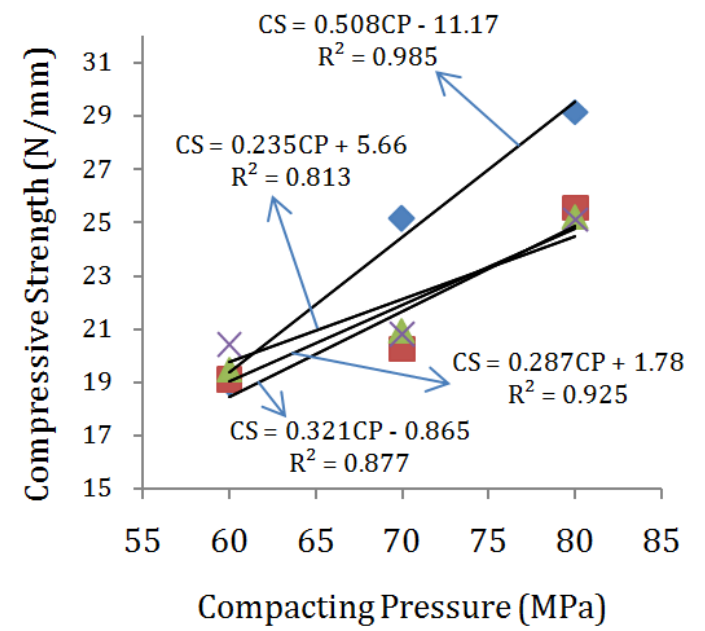

Fig. 7 Briquette compressive strength as a function of compacting pressure and binder level.

The maximum load withstanding capacity of a briquette before cracking is the compressive strength of a briquette which identifies the maximum weight a briquette can withstand during storage (Yank, Ngadi \& Kok 2016). Fig. 7 describes the compressive strength of briquettes produced in different blending proportions and at different compacting pressures. The compressive strength of briquette increases as the pressure increases and there is no significant change in compressive strength of briquettes at 5\%, $10 \%$ and $15 \%$ binder level at all pressures except briquettes produced without binder (S1). The lowest compressive strength $18.98 \mathrm{~N} / \mathrm{mm}$ was obtained for $\mathrm{S} 1$ at $60 \mathrm{MPa}$ and the highest compressive strength $29.15 \mathrm{~N} / \mathrm{mm}$ was obtained for $\mathrm{S} 1$ at $80 \mathrm{MPa}$. Stephen et al. (2013a) stated that if the briquette compressive strength is more than $19.6 \mathrm{~N} / \mathrm{mm}$ is 
reasonably suitable to use as a fuel for commercial purposes. The compressive strength of briquette samples $\mathrm{S} 1, \mathrm{~S} 2, \mathrm{~S} 3$ produced at $60 \mathrm{MPa}$ are less than $19.6 \mathrm{~N} / \mathrm{mm}$ and all other samples at all pressures are more than 19.6 $\mathrm{N} / \mathrm{mm}$. The results obtained in this study are consistent with the research findings by (Stephen et al. 2013a; Stephen et al. 2014; Stephen, Kwasi \& Nicholas 2013b). The mathematical regression equation for compressive strength (CS) which depends on blending proportion (BP) and compacting pressure $(\mathrm{CP})$ with the $\mathrm{R}^{2}$ and probability values are 0.839 and 0.000 respectively, is represented in Eq. (5).

$$
\begin{aligned}
& \text { Compressive strength }(\mathrm{N} / \mathrm{mm})=-0.138-0.765 \mathrm{BP}+ \\
& 0.350 \mathrm{CP}
\end{aligned}
$$

The theoretical and experimental values of compressive strength are shown in the Table 2.

High relaxed density, low relaxation ratio, high shattering index and high compressive strength are the indications of the better-quality briquette. The briquettes produced without binder i.e. S1 (0\% binder level) at 80 $\mathrm{MPa}$ have better properties compared to all other samples at all pressures except shattering index. Even though shattering index $93.6 \%$ of $\mathrm{S} 1$ at $80 \mathrm{MPa}$ is less than that of shattering index $98.6 \%$ of $\mathrm{S} 4$ at $80 \mathrm{MPa}$ is meeting the acceptable value more than $90 \%$. Thus, Briquette S1 (0\% binder level) at $80 \mathrm{MPa}$ is considered as a better property briquette and combustion characteristics were estimated for this sample.

\subsection{Combustion characteristics}

The combustion characteristics such as the proximate analysis, the ultimate analysis and the calorific value of ANH-SSS (60:40) briquette produced at $80 \mathrm{MPa}$ were estimated and compared with other briquettes.

It is reported that, as the moisture content and the ash content increases, it leads to many disadvantages like poor ignition, reduces the calorific value, generates more smoke, clinker formation in the combustion chamber
(Nayara et al. 2016). The results in Table 3 indicate that moisture content and ash content of ANH-SSS briquette are $5.75 \%$ and $2.48 \%$ respectively which are less than that of barley briquette and similar values were obtained for sawdust charcoal briquette. The volatile matter is an index of gaseous fuel and it is the responsible for ignitability, flame length in the combustion chamber. The volatile matter of most lignocelluloses materials vary from 70-86\% (Okey \& Kingsley 2016) and ANH-SSS briquette volatile matter $73.71 \%$ comes in the limit. Similar values were obtained for sawdust charcoal briquette $(71.00 \%)$ and barley briquette $(73.48 \%)$. Fixed carbon helps to generate heat during combustion and also helps to estimate the approximate calorific value of the fuel (Joseph, Francis \& Stephen 2012). The fixed carbon of ANH-SSS briquette is $18.19 \%$, similar results $20.7 \%$ and $21.07 \%$ were obtained for sawdust charcoal briquette and barley briquette respectively.

The ultimate analysis indicates the elemental chemical composition of fuel such as carbon, nitrogen, hydrogen, oxygen, sulphur, etc,. The carbon and hydrogen elements in the fuel contribute positively for the energy content in the fuel. The oxygen creates adverse effect on the energy release because oxygen combines with hydrogen leads to the formation of water vapour and reduces the availability of hydrogen for combustion (Nayara et al. 2016). Thus, high carbon content, high hydrogen content and low oxygen content are the desirable constituents of a good fuel. The amount of carbon, hydrogen and oxygen for ANH-SSS briquette are $65.86 \%$, $6.86 \%$ and $15.25 \%$ respectively which are better than that of sawdust charcoal briquette and barley briquette. It is reported that nitrogen and sulphur content in the fuel are less than $1 \%$ is a welcome sign which minimizes the emitting of pollutant gases like oxides of nitrogen and sulphur dioxide into the atmosphere (Joseph, Francis \& Stephen 2012). The nitrogen and sulphur content of ANHSSS briquette are $0.63 \%$ and $0.18 \%$ respectively; and similar results were obtained for sawdust charcoal briquette and barley briquette.

Table 3.

\begin{tabular}{|c|c|c|c|}
\hline Property & $\begin{array}{c}\text { Sawdust Charcoal } \\
\text { Briquette }^{\mathrm{c}}\end{array}$ & $\begin{array}{c}\text { Barley } \\
\text { Briquette }^{\mathrm{d}}\end{array}$ & $\begin{array}{c}\text { ANH-SSS Briquette } \\
\text { (ANH:SSS:BL=60:40:00) }\end{array}$ \\
\hline \multicolumn{4}{|c|}{ Proximate analysis (on as received basis, wt. \%) } \\
\hline Moisture & 5.70 & 9.55 & 5.75 \\
\hline Volatile matter & 71.00 & 73.48 & 73.71 \\
\hline Fixed carbon & 20.70 & 21.07 & 18.19 \\
\hline Ash & 2.60 & 5.46 & 2.48 \\
\hline \multicolumn{4}{|c|}{ Ultimate analysis (on dry and ash-free basis, wt. \%) } \\
\hline $\mathrm{C}$ & 53.07 & 44.98 & 65.86 \\
\hline $\mathrm{H}$ & 4.10 & 6.15 & 6.86 \\
\hline $\mathrm{N}$ & 0.28 & 0.68 & 0.63 \\
\hline $\mathrm{O}$ & 39.60 & 48.30 & 15.21 \\
\hline $\mathrm{S}$ & 0.302 & 0.30 & 0.18 \\
\hline Calorific value (MJ/kg) & 20.16 & 18.54 & 18.81 \\
\hline
\end{tabular}

Combustion characteristics of sawdust charcoal briquette, barley briquette and ANH-SSS briquette

c Joseph, Francis \& Stephen (2012), d Prabahar \& Kenneth (2014), e Present Study

\section{Conclusion}

This study concludes that ANH and SSS can be utilized for the production of good quality briquettes and use of black liquor with ANH and SSS as binder for the production of briquettes is not recommended. The briquette produced with a blending proportion of ANH:SSS:BL=60:40:00 at $80 \mathrm{MPa}$ has compressed density; $1040 \mathrm{~kg} / \mathrm{m}^{3}$, relaxed density; $962 \mathrm{~kg} / \mathrm{m}^{3}$, relaxation ratio; 1.0810 , shattering index; $93.01 \%$ and 
compressive strength; $29.15 \mathrm{~N} / \mathrm{mm}$. These property values are within the acceptable range. The ANH-SSS briquette have good combustion characteristics with low moisture content; $5.75 \%$, low ash content; $2.48 \%$, low nitrogen content; $0.63 \%$, low sulphur content; $0.18 \%$ and high volatile matter; $73.71 \%$, high fixed carbon; $18.19 \%$, high carbon content; $65.86 \%$, high hydrogen content; $6.86 \%$ and better calorific value; $18.81 \mathrm{MJ} / \mathrm{kg}$.

\section{References}

American Society for Testing and Materials (ASTM. D440-86) (1998) Standard test method of drop shatter test for coal. West Conshohocken 188-191

American Society for Testing and Materials (ASTM D2166-85) (2008) Standard test method of compressive strength of wood. West Conshohocken.

Antwi-Boasiako, C. \& Acheampong B.B. (2016) Strength properties and calorific values of sawdust-briquettes as wood-residue energy generation source from tropical hardwoods of different densities. Biomass and Bioenergy 85: $144-152$

Moses, D.R. \& Augustina, D.O. (2014) Some physical and mechanical properties of water lettuce (Pistia stratiotes) briquettes. American Journal of Science and Technology 1(5), 238-244.

Demirbas A (2009) Biofuels: Securing the Planet's Future Energy Needs, Green Energy and Technology, Springer-Verlag London Limited, ISBN 978-1-84882-010-4, London, UK.

Indian Standard:1350 (Part-I,1984), (Part-III,1969), (PartIV/Sec1,1974), (Part-IV/Sec 2,1975), (Part-II, 1970) Standard test method for proximate analysis, ultimate analysis and calorific value for coal and coke.

ISO: International standard ISO 3131 (1975) Standard test method for density of regular Solids, Geneva.

Joseph, O.A., Francis, K. \& Stephen, J.M. (2012) Physicochemical characteristics and market potential of sawdust charcoal briquette. International Journal of Energy and Environmental Engineering 3(20).

Kalyani, A.M., Ajit, P.R., Kailas, L.W. \& Nitin, K.L. (2016) Comparative study of different waste biomass for energy application. Waste Management 47, 40-45.

Karin, H. \& Rodrigo, C. (2012) World Biomass conference and exhibition on biomass for energy, Kent Nyström, Sweden.

Mishra, S.R., Mohanty, M.K., Das S.P. \& Pattanaik, A.K. (2012) Production of Bio-diesel (Methyl Ester) from Simarouba Glauca Oil, Research Journal of Chemical Sciences2(5), 6671.

Moonmoon, H., Dhiman, D. \& Baruah, D.C. (2014) Bioenergy potential from crop residue biomass in India.Renewable and Sustainable Energy Reviews 32, 504-512.

Mythili, R., Venkatachalam, P., Subramanian, P. \& Uma, D. (2013) Characterization of bioresidues for biooil production through pyrolysis. Bioresource Technology 138, 71-78.

Nayara, V.A., Ana, A.P., Angelica, de.C.O.C. \& Claudio, M.S. (2016) Evaluation of briquettes made from textile industry solid waste. Renewable Energy 91, 417-424.

Obi, O.F., Akubuo, C.O. \& Okonkwo, W.I. (2013) Development of an appropriate briquetting machine for use in rural communities. International Journal of Engineering and Advanced Technology 2(4), 578-582.

Okey, F.O. (2015) Evaluation of the physical properties of composite briquette of sawdust and palm kernel shell. Biomass Conversion and Biorefinery 5, 271-277.

Okey, F.O. \& Kingsley, C.O. (2016) Characterization of fuel briquettes made from a blend of rice husk and palm oil mill sludge. Biomass Conversion and Biorefinery 6(4), 449-456.

Paul, P.J., Rajan, N.K.S. \& Dasappa, S. (2014) Biomass fuel processing, Final project report of Advanced Biomass
Research Centre - Combustion, Gasification \& Propulsion Lab (CGPL), Department of Aerospace Engineering, Indian Institute of Science.

Prabahar, R. \& Kenneth, C. (2014) Comparison of gaseous and particle emissions produced from leached and un-leached agricultural biomass briquettes. Fuel Processing Technology 128, 359-366.

Rajaseenivasan. T., Srinivasan. V., Syed, M.Q.G. \& Srithar, K. (2016) An investigation on the performance of sawdust briquette blending with neem powder. Alexandria Engineering Journal 55, 2833-2838.

Sandeep, M. (2017) PM's flagship rural electrification hits a roadblock in Karnataka, Times of India, 15th March, p. 8.

Sangeeta, V. (2015) Pocket book of Agricultural Statistics, Government of India Ministry of Agriculture \& Farmers Welfare Department of Agriculture, Cooperation \& Farmers Welfare, Directorate of Economics \& Statistics, New Delhi.

Shiv, K.L., Ram, T., Mukesh, S., Ali, M. \& Arya, S. (2013) Sustainability of biodiesel production as vehicular fuel in Indian perspective, Renewable and Sustainable Energy Reviews 25, 251-259.

Soumya, S., Vaibhav, V.G., \& Kaustubha, M. (2012) Characterization of biomasses available in the region of North-East India for production of Biofuels, Biomass and Bio energy 45, 212-220.

Stephen, J.M., Kwasi, F.M., Nicholas, A.D. \& Joseph, O.A. (2013a) Briquettes from maize cobs and Ceibapentandra at room temperature and low compacting pressure without a binder. International Journal of Energy and Environmental Engineering 4(38).

Stephen, J.M., Kwasi, F.M. \& Nicholas, A.D. (2013b) Effect of species, particle size and compacting pressure on relaxed density and compressive strength of fuel briquettes. International Journal of Energy and Environmental Engineering 4(30).

Stephen, J.M., Kwasi, F.M. \& Nicholas, A.D. (2014) Relationship between Physico-Mechanical Properties, Compacting Pressure and Mixing Proportion of Briquettes Produced from Maize Cobs and Sawdust. Journal of Sustainable Bioenergy Systems 4,50-60.

Syamasundar, J. \& Shantha, J. (2008) Simarouba Glauca D C (Paradise tree), University of Agricultural Sciences, GKVK Bangalore 65 India 1-18.

Yank, A., Ngadi, M. \& Kok, R. (2016) Physical properties of rice husk and bran briquettes under low pressure densification for rural applications. Biomass and Bioenergy84, 22-30.

Yufu, Xu., Xianguo, Hu., Wendong, Li. \& Yinyan Shi. (2011) Preparation and Characterization of Bio-Oil from Biomass, Progress in biomass and bioenergy production, S ShahidShaukat, JanezaTrdine 9, 51000 Rijeka, Croatia 197-222 